\title{
ANALISIS METODE TOPSIS DALAM SISTEM PENDUKUNG KEPUTUSAN PENENTUAN GURU BERPRESTASI PADA SEKOLAH MENENGAH PERTAMA NEGERI 8 SAMARINDA
}

\author{
Anton Topadang ${ }^{1}$, Damar Nurcahyono ${ }^{2}$ \\ ${ }^{1,2)}$ Program Studi Teknik Informatika, Politeknik Negeri Samarinda \\ e-mail: ${ }^{1)}$ antontpd@gmail.com, ${ }^{2)}$ damarnc@ polnes.ac.id
}

\begin{abstract}
Abstrak - Guru adalah pendidik dan pengajar pada pendidikan anak usia dini jalur sekolah atau pendidikan formal, pendidikan dasar, dan pendidikan menengah. Guru berprestasi adalah guru yang memiliki kinerja melampaui standar yang telah ditetapkan oleh satuan pendidikan, yang mencakup kompetensi pedagogik, kompetensi kepribadian, kompetensi profesional, kompetensi sosial dan mampu menghasilkan karya inofatif yang diakui baik pada tingkat daerah, nasional dan/atau internasional. Dalam penelitian ini penulis menganalisis sistem pendukung keputusan dalam menentukan guru berprestasi menggunakan metode TOPSIS untuk membantu pihak manajemen dalam pengambilan keputusan. Hasil yang didapat dari penelitian ini berupa Pemodelan Technique for Order Preference by Similarity to Ideal Solution (TOPSIS) dan ranking calon guru berprestasi dan juga dapat dijadikan sebagai acuan dalam pembuatan aplikasi Sistem Pendukung Keputusan(SPK).
\end{abstract}

Kata Kunci : TOPSIS, Guru Berprestasi, SPK

\section{PENDAHULUAN}

Sekolah Menengah Pertama Negeri 8 Samarinda adalah salah satu SMP Negeri di Samarinda, yang terletak di kelurahan Baqa kecamatan Kecamatan Loa Janan Ilir. SMPN 8 Samarinda memiliki siswa yang cukup banyak, sehingga diharapkan siswa juga memiliki kemampuan akademik dan non-akademik yang baik. Hal ini tidak dapat tercapai tanpa adanya tenaga pendidik / guru yang memiliki kompetensi tinggi. Guna mendukung hal ini maka dibuat sistem pendukung keputusan (SPK) penentuan guru berprestasi SMPN 8 Samarinda.

Tujuan dari penelitian ini adalah menganalisis metode TOPSIS dalam sistem pendukung keputusan untuk menentukan guru berprestasi pada SMP Negeri 8 Samarinda. Hasil penelitian berupa model yang dapat digunakan dalam membangun aplikasi Sistem Pendukung Keputusan penentuan guru berprestasi berbasis online.

\section{TINJAUAN PUSTAKA}

Guru Berprestasi adalah guru yang memiliki kinerja melampaui standar yang telah ditetapkan oleh satuan pendidikan, yang mencakup kompetensi pedagogik, kompetensi kepribadian, kompetensi profesional, kompetensi sosial dan mampu menghasilkan karya inofatif yang diakui baik pada tingkat daerah, nasional dan/atau internasional.

Sistem pendukung keputusan/Decision support system (DSS) merupakan sistem informasi interakif yang menyediakan informasi, pemodelan, dan pemanipulasian data (Kusrini: 2007). Sistem ini digunakan untuk membantu pengambilan keputusan dalam situasi yang semi terstruktur dan situasi yang tidak terstruktur, dimana tidak seorang pun tahu secara pasti bagaimana keputusan seharusnnya dibuat (Alter: 2002).

Fuzzy Multiple Attribute Decision Making(FMADM) Logika Fuzzy dinyatakan dalam drajat dari suatu keanggotaan dan derajat dari kebenaran.

Oleh sebab itu sesuatu dapat dikatakan sebagian benar dan sebagian salah pada waktu yang sama (Yan : 1993). Fuzzy Multiple Attribute Decision Making (FMADM) adalah suatu metode yang digunakan untuk mencari alternatif optimal dari sejumlah alternatif dengan kriteria tertentu. Inti dari FMADM adalah menentukan nilai bobot untuk setiap atribut, kemudian dilanjutkan dengan proses perankingan yang akan menyeleksi alternatif yang sudah diberikan.

Pada dasarnya, ada 3 pendekatan untuk mencari nilai bobot atribut, yaitu pendekatan subyektif, pendekatan obyektif dan pendekatan integrasi antara subyektif dan obyektif. Masing-masing pendekatan memiliki kelebihan dan kelemahan. Pada pendekatan subyektif, nilai bobot ditentukan berdasarkan subyektifitas dari para pengambil keputusan, sehingga beberapa faktor dalam proses perankingan alternatif bisa ditentukan secara bebas.

Sedangkan pada pendekatan obyektif, nilai bobot dihitung secara matematis sehingga mengabaikan subyektifitas dari pengambil keputusan. (Kusumadewi : 2007). 
Ada beberapa metode yang dapat digunakan untuk menyelesaikan masalah FMADM. antara lain (Kusumadewi : 2006):

1) Simple Additive Weighting Method (SAW)

2) Weighted Product (WP)

3) ELECTRE

4) Technique for Order Preference by Similarityto Ideal Solution (TOPSIS)

5) Analytic Hierarchy Process (AHP)

MetodeTechnique ForOrder Preference by Similarityto Ideal Solution (TOPSIS) adalah satu metode pengambilan keputusan multi kriteria yang pertama kali diperkenalkan oleh Yoon dan Hwang (1981). TOPSIS menggunakan prinsip bahwa alternatif yang terpilih harus mempunyai jarak terdekat dari solusi ideal positif dan jarak terjauh dari solusi ideal negatif dari sudut pandang geometris dengan menggunakan jarak antara dua titik untuk menentukan kedekatan relatif dari suatu alternatif dengan solusi optimal.

Solusi ideal positif didefinisikan sebagai jumlah dari seluruh nilai terbaik yang dapat dicapai oleh setiap atribut, sedangkan solusi negatif-ideal terdiri dari seluruh nilai terburuk yang dicapai untuk setiap atribut. TOPSIS mempertimbangkan keduanya, jarak terhadap solusi ideal positif dan jarak terhadap solusi ideal negatif dengan mengambil kedekatan relatif terhadap solusi ideal positif. Berdasarkan perbandingan terhadap jarak relatifnya, susunan prioritas alternatif dapat tercapai.

Metode TOPSIS didasarkan pada konsep bahwa alternatif terpilih yang terbaik tidak hanya memiliki jarak terpendek dari solusi ideal positif tetapi juga memiliki jarak terpanjang dari solusi ideal negatif.

Langkah yang digunakan dalam mencari solusi dengan metode TOPSIS pada umumnya dikerjakan dengan melewati tahapan berikut (Perdana, 2014):

1. Menentukan kriteria yang digunakan sebagai poin yang menentukan apakah suatu pilihan merupakan solusi terbaik dalam suatu kasus. Kriteria dapat berupa factor-faktor apa saja yang mempengaruhi pengambilan keputusan.

2. Melakukan pembobotan kriteria. Dimana pada tahap ini kriteria-kriteria yang mempengaruhi pengambilan suatu keputusan diberi suatu nilai bobot berdasarkan presentasi kriteria tersebut dalam menentukan pengambilan keputusan.

3. Membangun normalized decision matrix. Elemen dari normalisasi ini ditunjukkan dalam Persamaan (1) berikut.

$$
r_{i j}=\frac{x_{i j}}{\sqrt{\sum_{i=1}^{m} x^{2}{ }_{i j}}}
$$

Dimana :

rij = hasil normalisasi decision matrix

$\mathrm{R}$;

$\mathrm{i}=1,2,3, \ldots, \mathrm{m}$;

$\mathrm{j}=1,2,3, \ldots \mathrm{m}$;

4. Membangun weighted normalized decision matrix yang ditunjukkan pada Persamaan (2) berikut.

$$
V=\left[\begin{array}{ccc}
w_{1} r_{11} & \cdots & w_{n} r_{1 n} \\
\vdots & \ddots & \vdots \\
w_{1} r_{m 1} & \cdots & w_{n} r_{m n}
\end{array}\right]
$$

5. Menentukan solusi ideal negative dan solusi ideal positif yang ditunjukkan pada Persamaan (3) dan Persamaan (4) berikut.

$A+=\left\{(\max V i j)\left(\min V i j \mid j \in J^{\prime}\right)\right.$, $\mathrm{i}=1,2,3, \ldots,, \mathrm{m}\}=\{V 1+, V 2+, \ldots, V m+\}$

$A^{-}=\left\{(\max V \mathrm{Vij})\left(\min V \mathrm{ij} \mid \mathrm{j} \in J^{\prime}\right)\right.$,

$\mathrm{i}=1,2,3, \ldots, \mathrm{m}\}=\left\{V 1^{-}, V_{2}-, \ldots, V m^{-}\right\}$ ...(4)

6. Menghitung separasi.

Merupakan suatu cara untuk menghitung atau mengukur jarak antara solusi alternative dengan solusi ideal positif maupun solusi ideal negative yang ditunjukkan pada Persamaan (5) dan persamaan (6) berikut.

$$
\begin{aligned}
S_{i}{ }^{+} & =\sqrt{\sum_{j=1}^{n}\left(v_{i j}-v_{j}{ }^{+}\right)^{2}} \\
S_{i}{ }^{-} & =\sqrt{\sum_{j=1}^{n}\left(v_{i j}-v_{j}\right)^{-}}
\end{aligned}
$$

Dengan $\mathrm{i}=1,2,3, \ldots ., \mathrm{n}$;

7. Menghitung kedekatan relatif terhadap solusi optimal yang ditunjukkan pada Persamaan (7) berikut.

$$
\begin{gathered}
C_{i}^{+}=\frac{S_{i^{-}}}{S_{i}{ }^{-}+S_{i}^{+}} \\
\text {Dengan } 0<\mathrm{C}<1 \text { dan } \mathrm{i}=1,2,3, \ldots, \mathrm{n} ;
\end{gathered}
$$

8. Memberikan ranking alternative yang dapat diurutkan berdasarkan nilai $\mathrm{Ci}+$ dari yang terbesar hingga yang terkecil.

\section{HASIL DAN PEMBAHASAN \\ 3.1 Analisa dan Identifikasi Kebutuhan Sistem}

Langkah-langkah penyelesaian adalah:

a.Menentukan alternatif 
Topadang dan Nurcahyono, Analisis Metode TOPSIS Dalam Sistem Pendukung Keputusan Penentuan Guru Berprestasi Pada Sekolah Menengah Pertama Negeri Samarinda

Ada 20 orang guru yang dijadikan alternatif sebagai sampel dalam penentuan guru berprestasi pada SMPN 8 Samarinda(data dummy) sebagai berikut: A1, A2, ..., A20.

\section{b. Menentukan Kriteria}

Terdapat lima kriteria yang digunakan

untuk menentukan guru berprestasi:

$\mathrm{C} 1=$ Kompetensi Pedagogik

$\mathrm{C} 2$ = Kompetensi Kepribadian

C3 = Kompetensi Profesional

$\mathrm{C} 4$ = Kompetensi Sosial

C5 = Kemampuan Inovasi

\section{c. Bobot Kriteria}

Pengambil keputusan memberikan bobot preferensi berdasarkan tingkat kepentingan kriteria yaitu $\mathrm{W}=(25,25,20,15,15)$ seperti dalam tabel 1 berikut:

Tabel 1. Bobot kriteria

\begin{tabular}{|l|c|c|c|}
\hline \multicolumn{1}{|c|}{ Kriteria } & Tipe & Bobot(W) & Bobot (W/100) \\
\hline Kompetensi Pedagogik & Benefit & 25 & 0,25 \\
\hline Kompetensi Kepribadian & Benefit & 25 & 0,25 \\
\hline Kompetensi Profesional & Benefit & 20 & 0,2 \\
\hline Kompetensi Sosial & Benefit & 15 & 0,15 \\
\hline Kemampuan Inovasi & Benefit & 15 & 0,15 \\
\hline
\end{tabular}

Dari kriteria di atas, maka dibuat suatu tingakat kepentingan kriteria berdasarkan nialai bobot yang telah ditentukan kedalam bilangan fuzzy. Rating kecocokan setiap alternatife pada setiap kriteria sebagai berikut : Sangat Rendah $(\mathrm{SR}) \quad=0 ; \operatorname{Rendah}(\mathrm{R})=0,25$; Cukup $(C)=0,50 ;$ Tinggi $(T)=0,75$ Sangat Tinggi $(\mathrm{ST})=1$. Nilai bobot tersebut dibuat dalam sebuah grafik supaya lebih jelas, seperti pada gambar 1 berikut:

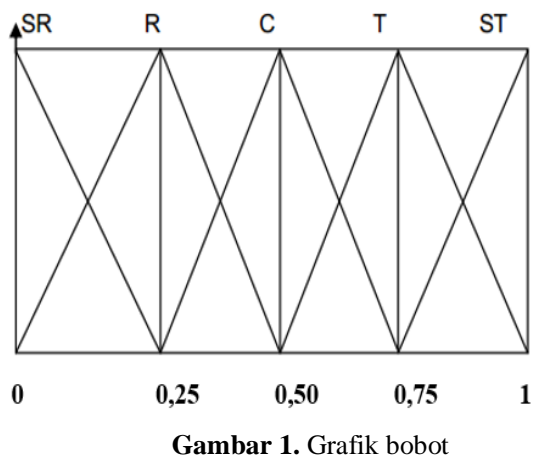

Keterangan :

$\mathrm{SR}=$ Sangat Rendah

$\mathrm{R}=$ Rendah

$\mathrm{C}=$ Cukup Tinggi

$\mathrm{T}=$ Tinggi

ST $=$ Sangat Tinggi

\subsection{Pembentukan bobot preferensi dan matriks keputusan}

Selanjutnya adalah pembentukan bobot preferensi dan matriks keputusan berdasarkan data rating keccokan alternatif yang diperoleh dari hasil seleksi awal seperti pada tabel berikut.

Tabel 2. Data alternatif

\begin{tabular}{|c|c|c|c|c|c|}
\hline Alternatif & Pedagogik & Kepribadian & Profesional & Sosial & Inovatif \\
\hline A1 & Sangat Tinggi & Tinggi & Rendah & Tinggi & Cukup \\
\hline A2 & Tinggi & Tinggi & Cukup & Sangat Tinggi & Sangat Tinggi \\
\hline A3 & Sangat Tinggi & Cukup & Sangat Tinggi & Rendah & Cukup \\
\hline A4 & Tinggi & Sangat Tinggi & Tinggi & Sangat Tinggi & Cukup \\
\hline A5 & Tinggi & Tinggi & Rendah & Rendah & Sangat Tinggi \\
\hline A6 & Sangat Tinggi & Cukup & Tinggi & Sangat Tinggi & Cukup \\
\hline A7 & Sangat Tinggi & Tinggi & Sangat Tinggi & Tinggi & Sangat Tinggi \\
\hline A8 & Tinggi & Tinggi & Sangat Tinggi & Sangat Tinggi & Cukup \\
\hline A9 & Sangat Tinggi & Tinggi & Rendah & Cukup & Sangat Tinggi \\
\hline A10 & Tinggi & Cukup & Tinggi & Tinggi & Cukup \\
\hline A11 & Sangat Tinggi & Sangat Tinggi & Sangat Tinggi & Cukup & Sangat Tinggi \\
\hline A12 & Tinggi & Tinggi & Cukup & Cukup & Sangat Tinggi \\
\hline A13 & Tinggi & Cukup & Tinggi & Sangat Tinggi & Tinggi \\
\hline A14 & Sangat Tinggi & Rendah & Rendah & Cukup & Sangat Tinggi \\
\hline A15 & Tinggi & Sangat Tinggi & Cukup & Rendah & Tinggi \\
\hline A16 & Rendah & Tinggi & Sangat Tinggi & Sangat Tinggi & Cukup \\
\hline A17 & Tinggi & Cukup & Tinggi & Tinggi & Sangat Tinggi \\
\hline A18 & Sangat Tinggi & Rendah & Cukup & Sangat Tinggi & Tinggi \\
\hline A19 & Tinggi & Tinggi & Sangat Tinggi & Tinggi & Sangat Tinggi \\
\hline A20 & Rendah & Tinggi & Cukup & Rendah & Sangat Tinggi \\
\hline
\end{tabular}

Berdasarkan tabel 2 selanjutnya dapat diperoleh rating kecocokan dari setiap alternatif terhadap setiap kriteria yang dituangkan pada tabel 3 berikut:

Tabel 3. Tabel Rating Kecocokan dari setiap alternatif pada setiap kriteria

\begin{tabular}{|c|r|r|r|r|r|}
\hline Alternatif & \multicolumn{1}{l}{ C1 } & \multicolumn{1}{l}{ C2 } & \multicolumn{1}{l}{ C3 } & \multicolumn{1}{l|}{ C4 } & \multicolumn{1}{c|}{ C5 } \\
\hline A1 & 1 & 0,75 & 0,25 & 0,75 & 0,5 \\
\hline A2 & 0,75 & 0,75 & 0,5 & 1 & 1 \\
\hline A3 & 1 & 0,5 & 1 & 0,25 & 0,5 \\
\hline A4 & 0,75 & 1 & 0,75 & 1 & 0,5 \\
\hline A5 & 0,75 & 0,75 & 0,25 & 0,25 & 1 \\
\hline A6 & 1 & 0,5 & 0,75 & 1 & 0,5 \\
\hline A7 & 1 & 0,75 & 1 & 0,75 & 1 \\
\hline A8 & 0,75 & 0,75 & 1 & 1 & 0,5 \\
\hline A9 & 1 & 0,75 & 0,25 & 0,5 & 1 \\
\hline A10 & 0,75 & 0,5 & 0,75 & 0,75 & 0,5 \\
\hline A11 & 1 & 1 & 1 & 0,5 & 1 \\
\hline A12 & 0,75 & 0,75 & 0,5 & 0,5 & 1 \\
\hline A13 & 0,75 & 0,5 & 0,75 & 1 & 0,75 \\
\hline A14 & 1 & 0,25 & 0,25 & 0,5 & 1 \\
\hline A15 & 0,75 & 1 & 0,5 & 0,25 & 0,75 \\
\hline A16 & 0,25 & 0,75 & 1 & 1 & 0,5 \\
\hline A17 & 0,75 & 0,5 & 0,75 & 0,75 & 1 \\
\hline A18 & 1 & 0,25 & 0,5 & 1 & 0,75 \\
\hline A19 & 0,75 & 0,75 & 1 & 0,75 & 1 \\
\hline A20 & 0,25 & 0,75 & 0,5 & 0,25 & 1 \\
\hline Jumlah : & $\mathbf{1 6}$ & $\mathbf{1 3 , 5}$ & $\mathbf{1 3 , 2 5}$ & $\mathbf{1 3 , 7 5}$ & $\mathbf{1 5 , 7 5}$ \\
\hline & & & & & \\
\hline
\end{tabular}

\subsection{Penyelesaian Dengan metode TOPSIS 1. Membuat Matriks Keputusan Ternormalisasi}


a. Menghitung matriks keputusan ternormalisasi terbobot kompetensi pedagogik, kepribadian, profesional, sosial, dan inovatif dengan menggunakan persamaan 1, sehingga diperoleh hasil perhitungan yang disajikan pada tabel 4 berikut.

Tabel 4. Matriks ternormalisasi

\begin{tabular}{|c|l|l|l|l|c|}
\hline Alternatif & C1 & C2 & C3 & C4 & C5 \\
\hline Normalisasi & R1 & R2 & R3 & R4 & R5 \\
\hline A1 & 0,2697 & 0,2372 & 0,0778 & 0,2255 & 0,1364 \\
\hline A2 & 0,2023 & 0,2372 & 0,1557 & 0,3007 & 0,2728 \\
\hline A3 & 0,2697 & 0,1581 & 0,3114 & 0,0752 & 0,1364 \\
\hline A4 & 0,2023 & 0,3162 & 0,2335 & 0,3007 & 0,1364 \\
\hline A5 & 0,2023 & 0,2372 & 0,0778 & 0,0752 & 0,2728 \\
\hline A6 & 0,2697 & 0,1581 & 0,2335 & 0,3007 & 0,1364 \\
\hline A7 & 0,2697 & 0,2372 & 0,3114 & 0,2255 & 0,2728 \\
\hline A8 & 0,2023 & 0,2372 & 0,3114 & 0,3007 & 0,1364 \\
\hline A9 & 0,2697 & 0,2372 & 0,0778 & 0,1503 & 0,2728 \\
\hline A10 & 0,2023 & 0,1581 & 0,2335 & 0,2255 & 0,1364 \\
\hline A11 & 0,2697 & 0,3162 & 0,3114 & 0,1503 & 0,2728 \\
\hline A12 & 0,2023 & 0,2372 & 0,1557 & 0,1503 & 0,2728 \\
\hline A13 & 0,2023 & 0,1581 & 0,2335 & 0,3007 & 0,2046 \\
\hline A14 & 0,2697 & 0,0791 & 0,0778 & 0,1503 & 0,2728 \\
\hline A15 & 0,2023 & 0,3162 & 0,1557 & 0,0752 & 0,2046 \\
\hline A16 & 0,0674 & 0,2372 & 0,3114 & 0,3007 & 0,1364 \\
\hline A17 & 0,2023 & 0,1581 & 0,2335 & 0,2255 & 0,2728 \\
\hline A18 & 0,2697 & 0,0791 & 0,1557 & 0,3007 & 0,2046 \\
\hline A19 & 0,2023 & 0,2372 & 0,3114 & 0,2255 & 0,2728 \\
\hline A20 & 0,0674 & 0,2372 & 0,1557 & 0,0752 & 0,2728 \\
\hline & & & & & \\
\hline
\end{tabular}

\subsection{Membuat Matriks Keputusan} Ternormalisasi Terbobot

Setelah membuat Matriks Ternormalisasi dibuat, selanjutnya membuat matriks keputusan ternormalisasi terbobot, dengan menggunakan persamaan 2. Hasil perhitungan dapat dilihat pada tabel5 berikut:

Tabel 5. Data normalisasi terbobot

\begin{tabular}{|c|c|c|c|c|c|}
\hline Alternatif & C1 & C2 & C3 & C4 & C5 \\
\hline $\begin{array}{c}\text { Kriteria } \\
\text { Terbobot }\end{array}$ & Y1 & Y2 & Y3 & Y4 & Y5 \\
\hline A1 & 0,0674 & 0,0593 & 0,0156 & 0,0338 & 0,0205 \\
\hline A2 & 0,0506 & 0,0593 & 0,0311 & 0,0451 & 0,0409 \\
\hline A3 & 0,0674 & 0,0395 & 0,0623 & 0,0113 & 0,0205 \\
\hline A4 & 0,0506 & 0,0791 & 0,0467 & 0,0451 & 0,0205 \\
\hline A5 & 0,0506 & 0,0593 & 0,0156 & 0,0113 & 0,0409 \\
\hline A6 & 0,0674 & 0,0395 & 0,0467 & 0,0451 & 0,0205 \\
\hline A7 & 0,0674 & 0,0593 & 0,0623 & 0,0338 & 0,0409 \\
\hline A8 & 0,0506 & 0,0593 & 0,0623 & 0,0451 & 0,0205 \\
\hline A9 & 0,0674 & 0,0593 & 0,0156 & 0,0225 & 0,0409 \\
\hline A10 & 0,0506 & 0,0395 & 0,0467 & 0,0338 & 0,0205 \\
\hline A11 & 0,0674 & 0,0791 & 0,0623 & 0,0225 & 0,0409 \\
\hline A12 & 0,0506 & 0,0593 & 0,0311 & 0,0225 & 0,0409 \\
\hline A13 & 0,0506 & 0,0395 & 0,0467 & 0,0451 & 0,0307 \\
\hline A14 & 0,0674 & 0,0198 & 0,0156 & 0,0225 & 0,0409 \\
\hline A15 & 0,0506 & 0,0791 & 0,0311 & 0,0113 & 0,0307 \\
\hline A16 & 0,0169 & 0,0593 & 0,0623 & 0,0451 & 0,0205 \\
\hline A17 & 0,0506 & 0,0395 & 0,0467 & 0,0338 & 0,0409 \\
\hline A18 & 0,0674 & 0,0198 & 0,0311 & 0,0451 & 0,0307 \\
\hline A19 & 0,0506 & 0,0593 & 0,0623 & 0,0338 & 0,0409 \\
\hline A20 & 0,0169 & 0,0593 & 0,0311 & 0,0113 & 0,0409 \\
\hline
\end{tabular}

\subsection{Menentukan matriks solusi ideal $\operatorname{positif}\left(\mathrm{A}^{+}\right)$dan matriks solusi ideal negatif $\left(A^{-}\right)$}

Menentukan matriks solusi ideal positif dan negatif yaitu dengan mencari nilai apakah setiap kriteria tersebut masuk ke dalam kategori biaya atau keuntungan, untuk menghitung matriks solusi ideal positif(+) dengan menggunakan persamaan 3 dan hasilnya pada tabel 6 berikut.

Tabel 6. Matriks solusi ideal positif dan negatif

\begin{tabular}{|r|r|r|r|}
\hline Alternatif & Positif(+) & Negatif(-) & $(\mathbf{D}+)+(\mathbf{D}-)$ \\
\hline A1 & 0,0558 & 0,0680 & 0,1239 \\
\hline A2 & 0,0406 & 0,0671 & 0,1077 \\
\hline A3 & 0,0559 & 0,0716 & 0,1275 \\
\hline A4 & 0,0307 & 0,0823 & 0,1130 \\
\hline A5 & 0,0633 & 0,0558 & 0,1191 \\
\hline A6 & 0,0472 & 0,0711 & 0,1183 \\
\hline A7 & 0,0228 & 0,0850 & 0,1078 \\
\hline A8 & 0,0331 & 0,0776 & 0,1107 \\
\hline A9 & 0,0555 & 0,0683 & 0,1238 \\
\hline A10 & 0,0513 & 0,0548 & 0,1061 \\
\hline A11 & 0,0225 & 0,0938 & 0,1164 \\
\hline A12 & 0,0464 & 0,0591 & 0,1055 \\
\hline A13 & 0,0468 & 0,0612 & 0,1080 \\
\hline A14 & 0,0788 & 0,0557 & 0,1345 \\
\hline A15 & 0,0500 & 0,0707 & 0,1207 \\
\hline A16 & 0,0580 & 0,0699 & 0,1279 \\
\hline A17 & 0,0471 & 0,0585 & 0,1056 \\
\hline A18 & 0,0677 & 0,0636 & 0,1314 \\
\hline A19 & 0,0283 & 0,0762 & 0,1045 \\
\hline A20 & 0,0711 & 0,0472 & 0,1183 \\
\hline
\end{tabular}

\subsection{Mencari Nilai Preferensi untuk setiap Alternatif}

Nilai preferensi untuk setiap alternatif didapat dari hasil proses perhitungan kedekatan setiap alternatif terhadap solusi ideal positif dan solusi ideal negatif sehingga didapat bahwa alternatif yang mempunyai nilai terbesar adalah alternatif yang terbaik.

Hasil nilai preferensi untuk setiap alternatil disajikan pada tabel 6 dalam urutan ranking dari terbesar ke terkecil berikut.

Tabel 6. Nilai preferensi setiap alternatif 
Topadang dan Nurcahyono, Analisis Metode TOPSIS Dalam Sistem Pendukung Keputusan Penentuan Guru Berprestasi Pada Sekolah Menengah Pertama Negeri Samarinda

\begin{tabular}{|c|c|c|}
\hline Alternatif & $\mathrm{V}$ & Ranking \\
\hline A11 & 0,8062 & 1 \\
\hline A7 & 0,7889 & 2 \\
\hline A19 & 0,7291 & 3 \\
\hline A4 & 0,7279 & 4 \\
\hline A8 & 0,7013 & 5 \\
\hline A2 & 0,6233 & 6 \\
\hline A6 & 0,6014 & 7 \\
\hline A15 & 0,5856 & 8 \\
\hline A13 & 0,5665 & 9 \\
\hline A3 & 0,5616 & 10 \\
\hline A12 & 0,5600 & 11 \\
\hline A17 & 0,5542 & 12 \\
\hline A9 & 0,5517 & 13 \\
\hline A1 & 0,5492 & 14 \\
\hline A16 & 0,5465 & 15 \\
\hline A10 & 0,5164 & 16 \\
\hline A18 & 0,4843 & 17 \\
\hline A5 & 0,4689 & 18 \\
\hline A14 & 0,4142 & 19 \\
\hline A20 & 0,3986 & 20 \\
\hline & & \\
\hline & & \\
\hline & 0 & 19 \\
\hline
\end{tabular}

Mobile. Malang: Universitas Islam Negeri Maulana Malik Ibrahim

\section{KESIMPULAN}

Berdasarkan hasil analisis dari penelitian yang telah dilakukan, maka dapat diambil kesimpulan sebagai berikut:

1. Pengujian dengan metode TOPSIS berhasil dilakukan dengan memberikan hasil berupa perankingan nilai prefersensi.

2. Alternatif A11 memiliki nilai tertinggi dalam perhitungan dengan metode TOPSIS sehingga dapat direkomendasikan untuk menjadi guru berprestasi, disusul A7, A19 dan seterusnya.

3. Hasil penelitian ini dapat dikembangkan lagi menjadi suatu aplikasi sistem.

\section{REFERENSI}

[1] Kursini. (2007). Konsep dan Aplikasi Sistem Pendukung Keputusan. Yogyakarta : Penerbit Andi

[2] Alter, Steven. (2002). Information System, Foundation of e-busiiness. London : Prentice Hall.

[3] Yan, J., 1993. Fuzzy Logic Control and Its Applications. Jurnal of Higher Education Studies.

[4] Kusumadewi, Sri \& Purnomo H. 2007. Aplikasi Logika Fuzzy untuk Pendukung Keputusan. Yogyakarta: Graha Ilmu

[5] Perdana, Reza. 2014. Sistem Rekomendasi Tempat Wisata Kuliner Menggunakan Metode TOPSIS Berbasis 